\title{
ROZWÓJ AZJATYCKICH SZTUK WALKI W POLSCE OD RECEPCJI TECHNIK FIZYCZNYCH DO POGŁĘBIONEJ REFLEKSJI KULTUROWEJ
}

\section{Poczq̨tek XX w. - uchylanie bambusowej kurtyny}

\begin{abstract}
Jujutsu (judo) - japońska walka wręcz oparta między innymi na rzutach, obaleniach, dźwigniach, uciskach na wybrane punkty anatomiczne, wykorzystuje się w niej również elementy broni białej
\end{abstract}

Obcowanie z kulturami Azji poprzez doświadczenia związane z pochodzącymi stamtąd sztukami walki ma już w Polsce ponad sto lat tradycji. Ich europejska historia zaczęła się w 1892 r., kiedy to Takashima Shibachi² zaczął propago-

\footnotetext{
${ }^{1}$ Mistrz chińskich i japońskich sztuk walki (naukę w tym zakresie rozpoczął w 1974 r., uczeń jednego z najwybitniejszych mistrzów kung fu drugiej połowy XX w. Wong Shun Leunga, uprawnienia mistrzowskie uzyskał od niego w 1995 r.). Od 1985 r. do chwili obecnej uczestniczy w wielu szkoleniach, badaniach i konferencjach związanych z azjatyckimi sztukami walki w Chinach (dyplomy ukończenia kursów instruktorskich Pekińskiego Instytutu Badawczego Wu Shu z 1986 i 1987 r.), Hongkongu (dyplom mistrzowski V.T.A.Ass. w 1994 r.), Japonii (dyplomy Stowarzyszenia Marobashikai), Tajlandii i Wietnamie, co przyniosło mu międzynarodowe uznanie. Praktykuje chińskie systemy kung fu Yongchun quan (Ving Tsun kuen) i Yang Taiji quan oraz japońskie Shinkage Ryu kenjutsu i kyudo. W latach 1983-1988 twórca i przewodniczący Krajowej Rady Instruktorów kung fu/wu shu. Od 1994 r. mistrz i dożywotni członek Hong Kong Ving Tsun Athletic Association oraz założyciel i prezes Europejskiego Stowarzyszenia Atletycznego Ving Tsun.

Duża część informacji zawartych w artykule jest wynikiem własnych doświadczeń i obserwacji Autora - Redakcja.

${ }^{2} \mathrm{~W}$ tekście zastosowano japońską zasadę pisowni japońskich imion własnych: nazwisko na pierwszym miejscu, imię - na drugim (Redakcja).
} 
wać w Wielkiej Brytanii jujutsu. W ślad za nim pojawili się kolejni nauczyciele, między innymi wybitny mistrz jujutsu i judo Tani Yukio (1881-1950). W latach 1903-1905 jujutsu pojawiło się i rozwijało na terenie Cesarstwa Niemieckiego. W 1912 r. szkołę Ericha Rahna (1885-1973), istotną dla rozwoju azjatyckich sztuk walki (ASW) w Europie w tamtym czasie, odwiedził sam Kano Jigoro (1860-1938), twórca współczesnego judo.

Zakłada się, że pierwsze kontakty z japońskimi sztukami walki Polacy mieli w czasie wojny rosyjsko-japońskiej (1904-1905), z 1904 r. pochodzi bowiem pierwsza pisemna relacja w języku polskim na temat sposobu ,walki zwyciężania poprzez ustępstwa". Pierwszy podręcznik szkoleniowy oparty na tej sztuce samoobrony wydano zaś we Lwowie trzy lata później.

Historycy tej formy ASW podają, że w wielu formacjach wojskowych i policyjnych armii walczących podczas I wojny światowej służyli Polacy poznający podstawy walki wręcz opartej na jujutsu. Po zakończeniu wojny i odzyskaniu niepodległości w Polsce znalazło się kilku instruktorów dobrze wyszkolonych we Francji.

W wolnej Polsce jujutsu zaczęto trenować w Towarzystwie Gimnastycznym Sokół, YMCA (z ang. Young Men's Christian Association, Związek Chrześcijańskiej Młodzieży Męskiej), szkołach policyjnych oraz w Centralnej Szkole Wojskowej Gimnastyki i Sportu w Poznaniu (CSWGiS). Było też zalecane jako element wychowania fizycznego oraz przedmiotu przysposobienie wojskowe dla uczniów gimnazjów. W okresie międzywojennym silne ośrodki jujutsu działały na terenie Warszawy, Poznania, Krakowa, Łodzi, Katowic, Lwowa i Wilna.

Wszystkie te działania doceniały bardziej walory fizyczne ASW oparte na jujutsu niż wymianę międzykulturową i tak istotne doskonalenie duchowe. W tym okresie w kulturze europejskiej dominowały bowiem przede wszystkim wpływy filozofów i mistyków pochodzących z Indii. Zapewne z czasem sięgnięto by do właściwej poszczególnym ASW nadbudowy, gdyby procesu tego nie przerwała II wojna światowa, a po niej zmiany ustrojowe i związana z tym polityka okresu stalinowskiego (do 1955 r.).

\section{Lata 50. i 60. XX w. - okres pionierów i romantyków}

Od 1945 do 1955 r. walkę wręcz opartą na zapasach, boksie i elementach jujutsu propagowano jedynie w ramach wyszkolenia wojska (znalazło się w programie Akademii Wychowania Fizycznego pod koniec lat 40.) i milicji. Jednocześnie część wiedzy na temat ASW przywozili do kraju powracający z Wielkiej Brytanii polscy żołnierze jednostek Kierownictwa Operacji Specjalnych, czyli SOE (cichociemni), kompanii komandosów i brygady spadochronowej. W latach późniejszych 
informacje o tych ASW trafiały fragmentarycznie, szczególnie na terenie Śląska, do grup sekcji samoobrony ćwiczących pod auspicjami Towarzystwa Krzewienia Kultury Fizycznej (TKKF).

W 1957 r. w wyniku odwilży po okresie stalinowskim w ramach działających sekcji AWF i milicyjnych (Gwardyjskich) powstał Polski Związek Judo (PZ Judo). W środowiskach akademickich zaczęły się wtedy gwałtownie rozwijać sekcje sportowe judo i samoobrony, umownie zwanej jujutsu. To pokolenie judoków w środowisku nazywano romantycznym. Po nich nastała dopiero era judoków naukowych.

Znaczącym krokiem w rozwoju polskiego judo w kierunku jego azjatyckich korzeni, metod treningowych i właściwej mu nadbudowy było szkolenie prowadzone od 1969 r. przez mistrza Tomitę Hiromiego. Odwiedzał on potem Polskę wielokrotnie, co z czasem zaowocowało medalami olimpijskimi i wykształceniem rodzimej kadry trenerskiej.

W latach 70. i 80. jujutsu stało się szansą na kontynuację kariery dla byłych zawodników judo bądź wojskowych instruktorów samoobrony. Bazą była forma samoobrony wywodząca z judo, zwana goshinjutsu. Równocześnie takie podejście do tej ASW funkcjonowało już od dziesiątków lat w Europie. $Z$ tego powodu przekaz kulturowy pomiędzy tradycyjnymi formami japońskich szkół jujutsu a ich europejskimi odpowiednikami został zerwany, zanim trafił do Polski, nadbudowę zaś oparto przede wszystkim na kulturze europejskiej. Dopiero w drugiej połowie lat 80. niektóre szkoły nurtu goshinjutsu zaczęły poszukiwać - i to skutecznie tradycyjnych przekazów tej ASW. Wiele pozostało jednak przy znanej już formie, wchłaniając jedynie niektóre elementy z karate czy aikido. Inne związały się na jakiś czas z wietnamskim vo, na przykład ze szkołą Vo Quyen.

\section{Poczq̨tki japońskiego karate i chińskiego kung fu}

Obok mającego coraz silniejszą pozycjęjudo na przełomie lat 60. i 70. popularność zaczęło zdobywać karate. W 1969 r. Bogusław Skut, jeden z czołowych polskich judoków i trenerów, kierownik Studium Wychowania Fizycznego na SGPiS (obecna Szkoła Główna Handlowa), wyraził zgodę na udostępnienie sali treningowej i utworzenie pierwszej w Polsce studenckiej sekcji karate, jeszcze takiego „znad Wisły”. Pionierami jujutsu, karate, a także kung fu w Polsce stali się więc byli zawodnicy judo.

$\mathrm{Na}$ tym początkowym etapie rozwoju ASW, obok zainteresowania kulturami i historią Azji, istotną rolę odegrały przede wszystkim takie czynniki, jak:

- fascynacja ciałem, jego sprawnością oraz możliwościami;

- moda na elementy kultur azjatyckich, a przede wszystkim na kimono; 
- możliwość przynależenia do elitarnej grupy społecznej. Ten aspekt zaczął tracić na znaczeniu po 1989 r., a elitarność poszczególnych sztuk walki zaczęła się wiązać z innymi ich aspektami;

- uzupełnianie sprawności fizycznej nabywanej przez dzieci w szkołach. Ten aspekt w ostatniej dekadzie XX w. i pierwszej XXI w. w takich odmianach ASW, jak: karate, aikido czy kung fu zaczął dominować. Oceniamy, że z tej grupy wiekowej wciąż wywodzi się od 50\% do $80 \%$ wszystkich obecnie ćwiczących.

\section{Pierwsi rodzimi mistrzowie ASW}

Karate (karatedo) - japońska walka wręcz oparta między innymi na uderzeniach, kopnięciach, obaleniach, dźwigniach i zastosowaniu broni białej

Wraz z gierkowską epoką otwarcia się Polski na Zachód w naszym kraju rozpoczął się rozwój różnych ASW. Zainteresowanie nimi w drugiej połowie lat 70. rosło wręcz lawinowo. Dzięki uczącym się w Krakowie studentom z USA i Kanady w Polsce pojawiły się w latach 1971-1972 pierwsze szkoły chińskiego kung fu mistrza D.K. Paia (1930-1993), potem Sing Ming Lee ze stylu Chow Gar. W tym samym roku w Łodzi nauczanie japońskiego karate rozpoczyna studiujący tam Shimoda Chiyomaro. W latach 1973-1975 w Krakowie, Szczecinie, Łodzi i Poznaniu powstaje wiele grup ćwiczących karate w odmianach Shotokan i Kyokushin. Z czasem utworzyły one przy Zarządzie Głównym TKKF Centralną Komisję Karate, która w 1980 r. przekształciła się w Polski Związek Karate oraz (1997) Polski Związek Karate Tradycyjnego (PZKT).

Dzięki pisarzowi i podróżnikowi Jackowi Pałkiewiczowi, jego kontaktom i sponsorom we Włoszech (lata 1973-1974) karate na dobre zagościło w Warszawie i w Polsce. Wtedy pojawiły się pierwsze stopnie mistrzowskie (1 i 2 dan) po egzaminach przeprowadzonych przez Włocha Augusta Basilego ze stylu Shotokan. Zaraz po tym podobne stopnie mistrzowskie pojawiły się też w innych odmianach.

Kluczowe znaczenie dla asymilacji ASW, takich jak karate i kung fu w ich tradycyjnej formie, miał działający w Warszawie, a promieniujący na kraj Studencki Klub Karate SGPiS, potem również klub karate Politechniki Warszawskiej. Oczywiście miejsc, gdzie ćwiczono w Warszawie w drugiej połowie lat 70., było więcej. Na SGPiS dzięki amerykańskiemu studentowi polskiego pochodzenia ćwiczący mieli w 1975 r. pierwszy kontakt z koreańskim wojskowym systemem Hapkido. 
Szczególnym fenomenem w tamtych warunkach ustrojowych była od $1977 \mathrm{r}$. mocna pozycja na polskim rynku ASW (poprzez sekcje SGPiS) okinawskiego karatedo Doshinkan. Była to pierwsza tradycyjna szkoła karatedo (do w nazwie karate oznacza drogę duchową tej sztuki walki w przeciwieństwie chociażby do jutsu oznaczającego przede wszystkim umiejętność walki; samo słowo karate ma obecnie bezpośrednie związki z rywalizacją sportową), kompletna pod względem systemowym, pochodząca z pierwszej ręki od wybitnego mistrza posiadającego tytuł hanshi i 10 dan, Ichikawy Isao (1935-1996), wychowanka Toyamy Kankena (1888-1966).

Nadzwyczaj inspirujące były treningi z Ichikawą sensei, kiedy na wiele sposobów interpretował te same ruchy pojedynczego kata. Ta forma treningu stawała się już przekazem karate wykraczającym poza słowa i ruch, rodzącym wraz z latami treningu pierwsze wewnętrzne postrzegania intuicyjne. Tu ujawniały się po raz pierwszy azjatyckie duchowe moce, mające konotacje z japońską ideą shin/kokoro.

Shin (kokoro) - (pierwotne chińskie odpowiedniki to xin [serce (xin zang), myśli (xin li),
stan emocjonalny (xin qing)] i shen [bóstwo, duch, dusza; ma jeszcze kilka innych za-
stosowań]) jap. umysł, dusza, serce, rdzeń, wewnętrzna siła, szpik. Japońskie słowa po-
chodne to: fudoshin, boshin, mushin, mugashin, heijoshin, shoshin.
Najstarszym japońskim źródłem informacji na temat shin/kokoro jest tekst z XVII w.
buddyjskiego mnicha zen Soho Takuana, znany jako Fudochishinmyoroku. Omawia stan
umysłu w stanie fudo-shin, który wciąż się porusza (reaguje na informacje ze zmysłów),
a mimo to jest w nim (skoncentrowany) środek, który nie poddaje się żadnemu ruchowi,
pozostając zawsze taki sam. Główna teza Takuana to zachowanie całkowitej płynności
umysłu (kokoro, inaczej shin) poprzez uwolnienie się od intelektualnych deliberacji i za-
burzeń wywoływanych emocjami.
W kontekście ASW oznacza umysł reagujący spontanicznie, naturalnie, efektywnie i bez
chwili wahania. Aby to osiągnąć, trzeba było się poddać procesowi szkolenia z zaangażo-
waniem, konsekwencją i pasją, osiągając dla technik walki stan naturalnych reakcji bez
konieczności angażowania świadomej nad nimi kontroli. Jest to ostateczne mistrzostwo
osiągane wyłącznie poprzez ciężki trening fizyczny i duchowy, tj. osiągnięcie sukcesu
w konfrontacji z własnymi lękami i słabościami.
Zob. Stephan M. Fabian, Fudoshin and Its Continuing Relevance, ,Furyu”, nr 9; Rein-
hard Kammer, The Way of the Sword. The Tengu Geijutsu Ron of Chozan Shissai, Arkana,
London, Boston \& Hanley, 1986; John Stevens, Sword of No-Sword: Life of Master War-
rior Tesshu, Shambhala Publications 1995; Yagyū Munenori, Heiho kadensho - księga
przekazów rodzinnych o sztuce wojny, Diamond Books, Bydgoszcz 2002; Yagyū Mune-
nori, The Life-Giving Sword. Secret Teachings from the House of Shogun, Kodansha 2003.


Na początku lat 80. zaczyna się rozwijać w Polsce druga po Doshinkan karatedo szkoła tradycyjnego karate z Okinawy - Shorin Ryu pochodząca z przekazu rezydującego we Francji mistrza Chinena Kenyu (ur. 1944).

Znaczny i interesujący rozwój karate jako ASW, wykraczający poza dotychczasowe reprezentowane na polskim rynku kierunki karate sportowego i mającego już ugruntowaną pozycję karatedo Doshinkan i Shorin Ryu, rozpoczął się dopiero w latach 90. i później. Ważącymi postaciami stali się tu mistrzowie stylów: Oyama Shigeru z Oyama Ryu, Oyata Seiyu z Ryute, Higaonna Morio i jego uczniowie z Goju Ryu, Shimabukuro Yokinobu i jego uczniowie z Uechi Ryu oraz Patrick McCarthy z Koryu Uchinadi.

Kung fu - chińska walka wręcz oparta między innymi na uderzeniach, kopnięciach, obaleniach, dźwigniach i zastosowaniu broni białej (pierwowzór karatedo, taekwondo, sama nazwa, upowszechniona na Zachodzie od lat 70. XX w., pochodzi z dialektu prowincji Fujian). Jego odległym odpowiednikiem jest współczesna sportowa odmiana chińskich sztuk walki zwana wu shu

W 1977 r. z inspiracji sekcji karatedo SGPiS udało się wypożyczyć z Filmoteki Polskiej na specjalny seans w nieistniejącym już warszawskim kinie Polonia film z Bruce'em Lee (1940-1973) Enter the Dragon (słynne Wejście smoka, film oficjalnie trafił na polskie ekrany dopiero w połowie lat 80.). Przed kinem mimo jednodniowej niewielkiej informacji były takie tłumy, że ogłoszono (nielegalne!) powtórzenie seansu następnego dnia rano. Dopiero wtedy z niemal dwugodzinnym opóźnieniem ci, którzy mieli bilety, mogli wejść na salę. Tego emocjonalnego szaleństwa (pierwszy taki film w Polsce) nie da się dziś z niczym porównać. W jego efekcie w tym i następnym roku sformowały się i ujawniły w Warszawie kolejne grupki zapaleńców ćwiczące chińskie kung fu, pochodzące nadal z przekazu jeszcze z drugiej ręki, czyli amerykańskiego, wietnamskiego i niemieckiego.

W 1983 r. z inicjatywy autora tekstu i małego grona entuzjastów na Politechnice Warszawskiej odbył się pierwszy ogólnopolski zjazd i pokazy ćwiczących różne odmiany ASW ze słowem kung fu w nazwie. W efekcie zjazdu i pokazów powstała Krajowa Rada Instruktorów Kung Fu przy Zarządzie Głównym TKKF. Następstwem tego faktu i zainteresowania Ambasady Chińskiej Republiki Ludowej (ChRL) w Polsce były wizyty w latach 1984-1985 ministra sportu Chin w polskich klubach kung fu, zapoczątkowujące propagowanie nowej formy sportu związanej czy wywodzącej się z kung fu pod nazwą wu shu (w jęz. chińskim sztuki walki/wojenne). 
W 1985 r. odbyła się I Międzynarodowa Konferencja i Turniej, tak zwany zaproszeniowy, wu shu w Xi'anie, stolicy prowincji Shaanxi, gdzie podjęto decyzję o powołaniu światowego ruchu tego sportu. W kolejnych latach w ChRL zorganizowano pierwsze międzynarodowe kursy instruktorów i sędziów wu shu. Od początku w tym ruchu działali Polacy. Wieloletni opór przeciwko rozwojowi chińskich sztuk walki stawiało polskie środowisko karate, nawet przy użyciu argumentów politycznych, przez co Polski Związek Wu Shu powstał dopiero na początku XXI w. Na igrzyskach olimpijskich w Pekinie (2008) wu shu stało się sportem pokazowym (dyscypliną pretendującą do objęcia olimpijską klasyfikacją medalową).

Jednocześnie obok wu shu bezprecedensowy międzynarodowy poziom i sukces osiągnęły polskie style kung fu, szczególnie takie jego odmiany, jak: Choy Lee Fut, Ving Tsun kuen, Hung Gar i Qixing Tang Lang quan (nazwy stylów i systemów kung fu pochodzą z różnych dialektów języka chińskiego. Forma zapisu nawiązuje do ich popularnych transkrypcji stosowanych na Zachodzie).

W ostatniej dekadzie XX w. pojawiały się kolejne na polskim rynku ASW odmiany tradycyjnego kung fu (niektóre debiutowały w Polsce jeszcze w latach 80.) - Chen Taiji quan, Yang Taiji quan, Xingyi, Chuojiao Fanzi quan i He quan. Wieloletnie szkolenia w Azji, udziały w międzynarodowych konferencjach, pokazach i zawodach, wreszcie pomoc wyszkolonych już praktyków pracujących i mieszkających w Chinach spowodowały, że aspekty psychofizyczne i kulturowe stawały się w tym okresie jednakowo ważne w ćwiczeniu i rozwoju chińskich odmian ASW.

\section{Kendo-japońska sportowa szermierka bambusową atrapą miecza samurajskiego}

Kendo zawitało do Polski w 1973 r. wraz z japońskim studentem Mizushimą Takao, który rozpoczął studia w Łodzi i przywiózł odpowiedni sprzęt treningowy. Powstała pierwsza studencka sekcja w Łodzi, a rok później - gdy Takao zmienił uczelnię - w Warszawie. W 1975 r. w studenckim klubie Stodoła odbył się pierwszy, już na mistrzowskim poziomie, pokaz tego sportu w wykonaniu grupy Japończyków pod przewodnictwem Ando Kozo sensei (1940-2003), który stał się wieloletnim opiekunem i mentorem polskiego kendo. Z jego inicjatywy japońscy mistrzowie zaczęli uczestniczyć w dorocznych krajowych obozach treningowych, a także pomagać Polakom w czasie ich wizyt szkoleniowych w Japonii. Stan wojenny lat 80 . też nie stanowił tu przeszkody. Wraz z kendo trafiło do Polski - jako element jego treningu - iaido (ćwiczenia wykonywane ostrym mieczem, jako forma walki z cieniem), które z czasem zaczęło żyć własnym życiem. Z Ando sensei 
przyjacielską wymianę umiejętności miał nasz słynny olimpijczyk i fechmistrz szabli Wojciech Zabłocki. Skończyło się na obopólnym trafieniu.

Wieloletnie starania adeptów tej dyscypliny sportu doprowadziły ostatecznie w 2001 r. do powstania Polskiego Związku Kendo. W ramach związku zaczęły wtedy działać jako samodzielne komisje także grupy ćwiczące iaido i jodo (walki kijem o długości miecza kendo).

\section{Taekwondo - koreańska walka wręcz oparta przede wszyst- kim na kopnięciach i uderzeniach, w niektórych odmian- ach także na obaleniach i dźwigniach}

W połowie lat 70. pojawiło się w Polsce koreańskie tangsodo, znane współcześnie jako taekwondo. Lata 1977-1978 to wizytacje generała Choi Hong Hi, twórcy nowoczesnego systemu koreańskiego taekwondo (World Taekwondo Federation, WTF) i jego grupy instruktorów w polskich klubach, sekcjach sztuk walki oraz jednostkach wojskowych z pokazami i propozycjami współpracy. Generał w pewnym momencie zmienił zapatrywania polityczne i zaczął propagować socjalistyczną wersję taekwondo (International Taekwondo Federation, ITF), co doprowadziło do rywalizacji dwóch stowarzyszeń międzynarodowych.

Gen. Choi Hong Hi (1918-2002) w Korei Południowej pracował między innymi dla Koreańskiej Centralnej Agencji Wywiadowczej (KCIA). Dla potrzeb wojska opracował na chińskich i japońskich wzorach program treningowy walki wręcz, który z czasem ewoluował w taekwondo.

Po odejściu z armii jakiś czas przebywał w Kanadzie, a potem pojawił się w Korei Północnej, gdzie wprowadził nieco zmodyfikowaną wersję wcześniejszego taekwondo.

W Korei Południowej został uznany za zdrajcę.

W następnych latach w Polsce zaczął umacniać się ruch związany z ćwiczeniem koreańskich sportów walki, który zyskał dodatkowy impuls po wprowadzeniu taekwondo do programu igrzysk olimpijskich (Sydney 2000). Polski Związek Taekwondo (związany z ITF) powstał w 1991 r., a Polski Związek Taekwondo Sportowego (związany z WTF) w 1992 r. Z czasem ten drugi zmienił nazwę (2007) na Polski Związek Taekwondo Olimpijskiego.

Na początku lat 80. na krótko trafił do Polski północnokoreański wojskowy styl Kyoksul. Wielu ówczesnych praktyków karate i taekwondo z Warszawy i Trójmiasta nawiązało z nim współpracę.

Lata 80. i 90. to rozwój w kraju grup ćwiczących taekwondo oparte na jego różnych południowokoreańskich odmianach wojskowych, tworzonych jeszcze na 
zapotrzebowanie armii USA w czasie wojny wietnamskiej, takich jak: Hapkido, Hwarangdo, Kyuksolwan itp.

\section{Aikido - japońska walka wręcz oparta przede wszystkim na rzutach, obaleniach i dźwigniach, również z wykorzy- staniem elementów broni bialej}

W 1976 r. powstała w Szczecinie w ramach TKKF pierwsza polska sekcja aiki$d o$, ale ruch ten zaczął się szybko rozwijać dopiero w połowie lat 80 ., by ugruntować swoje miejsce na mapie ASW w Polsce w latach 90. i w pierwszej dekadzie XXI w. Ten niezbędny czas wynikał między innymi ze sztywnych reguł nauczania i rozwoju adeptów oraz z koordynacji szkolenia przez jedną międzynarodową organizację, na czele której stoją kolejni spadkobiercy z rodu twórcy, Ueshiby Moriheia (1883-1969). Z czasem zaczęło jednak działać kilka mniejszych stowarzyszeń założonych przez uczniów Ueshiby. Dzięki temu czasowi i od początku kompletnej metodzie szkolenia psychofizycznego pojawiło się kilku polskich wybitnych praktyków aikido.

$V o$ - wietnamska walka wręcz oparta przede wszystkim na kopnięciach i uderzeniach, w niektórych odmianach także na obaleniach, dźwigniach i broni białej

Jakkolwiek odmiany ASW związane z wietnamskim vo trafiły do Polski pod koniec lat 70. dzięki studentom wietnamskim, to jego autentyczny rozwój zaczął się dopiero w latach 80. Najpierw pojawiła się wspomniana szkoła Vo Quyen, którego nauczyciel i mistrz Trung La Duc pozostał na stałe w Polsce, działając przez wiele lat w Bydgoszczy i rozwijając filie szkoły w Pszczynie i Tychach, a potem szkoła Vo-vin-nam międzynarodowej organizacji Viet-vo-dao, której niekwestionowanym liderem został Ryszard Jóźwiak. Dzięki niemu vo rozwinęło się i umocniło w latach 90. także w Europie Centralnej i Wschodniej.

ASW rozwijają się również prężnie w pierwszej dekadzie XXI w. w działających w kraju azjatyckich diasporach, które sprowadzają nauczycieli jedynie na własne potrzeby, np. w środowisku wietnamskim adepci uczestniczą w dorocznych wizytach szkoleniowych mistrza Nguyen Ngoc Noia. 


\section{Lata 80. XX w. - złote lata sztuk i sportów walki w Polsce}

W pierwszej połowie lat 80 . następuje w kraju coraz wyraźniejszy podział ASW na ich wersję tradycyjną i sportową. Karate dzieli się na trzy nurty: okinawskie karatedo i japońskie karate sportowe oparte na poszczególnych stylach oraz modern karate przekształcone w full-contact karate, które ostatecznie przyjęło formę kick boxingu. W latach 90. do tej ostatniej formy uprawiania ASW dołączyły w Polsce tajboks (muay thai) i chińska sanda. To w tym okresie następuje rozłam w filozofii podejścia do sposobów treningu tych sztuk, ich kierunków rozwoju, przesłań etycznych, wychowawczych czy kulturowych.

Motywem wyjściowym ćwiczenia tradycyjnych azjatyckich sztuk walki były i pozostają takie równoważne ich aspekty, jak:

- ciało i jego poziom sprawności, zdrowie, moc (łączenie siły mięśni i energii wewnętrznej), wreszcie systemowa technika walki ograniczona czasem i przestrzenią;

- dyscyplina duchowa w dążeniu do mistrzostwa;

- umysł, czyli zrozumienie i wykorzystywanie strategii walki poszczególnych systemów ASW, koncentracja i ostatecznie rodzaj właściwych im iluminacji.

Motywem wyjściowym azjatyckich sportów walki stały się przede wszystkim punkty przyznawane wyłącznie za technikę ograniczoną regulaminami. O ile pod koniec lat 70. liczba ćwiczących sztuki/sporty walki ASW nie przekraczała w Polsce 25-30 tys. osób, to dekadę później - według prezentowanych w tamtym okresie ocen polskich związków sportowych, ogólnopolskich stowarzyszeń ASW i ognisk TKKF - osiągnęła liczbę około 100 tys. stale ćwiczących uczestników rozmaitych zajęć z różnych dyscyplin. W drugiej dekadzie XXI w. liczbę ćwiczących ocenia się już na 200-300 tys. (wystąpienie minister sportu Joanny Muchy podczas Pucharu Świata w Karate Tradycyjnym 15 czerwca 2013 r. w Lublinie).

\section{Lata 90. i wejście w XXI w. - komercjalizacja ASW i zderzenie z tradyciq}

Lata 90. to dotarcie do Polski wielu różnych komercyjnych odmian sztuk i sportów walki z drugiej, trzeciej, a nawet czwartej ręki, walki w klatkach i rozwój metod jedynie inspirowanych azjatyckimi sztukami/sportami walki. Te doświadczenia są tak odległe od pierwowzorów i kultur azjatyckich, że zakładając, iż swoją metodyką nie szkodzą zdrowiu ćwiczących, stały się zupełnie nowymi doświadczeniami w tym zakresie.

W latach 90. po zmianach ustrojowych w Polsce zaczęło się pojawiać też wielu wybitnych mistrzów ASW o niezwykłym poziomie wiedzy i otwartości, pozba- 
wionych przy tym charakterystycznego wcześniej u mistrzów azjatyckich lekceważenia uczniów innych nacji. Chcieli i nauczali oni każdego, kogo zaakceptowali jako ucznia, na najwyższym możliwym poziomie, uzależniając to tylko od jego zaangażowania, a nie od koloru skóry. To jednak wymuszało specyficzną formę nauki, bo - jak mawiał i uczył wybitny mistrz kung fu z XX w. Wong Shun Leung (1935-1997) - nie da się poważnie nauczać dużej grupy osób ćwiczących w formie musztry, osób, z którymi nie tworzy się więzi zgodnej z ideami wywodzącymi się od Konfucjusza, które mają czas, by przyswajać, pojąć umysłem i odczuwać.

Coraz wyższy poziom zaczęły osiągać ASW, których początki w Polsce sięgały lat 70., stając się teraz w pełni kompletnymi, systemowymi metodami kształcenia psychofizycznego. Przykładem jest chociażby system kung fu Choy Lee Fut. Zadomowił się on na polskim rynku w drugiej połowie lat 80 . Po prawie dziesięciu latach intensywnych doświadczeń, w tym u bezpośredniego spadkobiercy twórcy tej szkoły pochodzącego z rodu Chen - dr. Chen Yongfa, polscy instruktorzy osiągnęli potwierdzony oficjalnie poziom mistrzowski (taki dokument w przeciwieństwie do stopni dan w karate otrzymuje się po wielu latach raz w życiu). W ślad za tym doszły, na podobnym poziomie, doświadczenia związane z ćwiczeniami qigong (zdrowotne ćwiczenia gimnastyczne i oddechowe), a lider tego systemu i jeden z prekursorów polskiego kung fu, Grzegorz Ciembroniewicz, został uznany przez amerykańską organizację World Karate Union w 1999 r. za najlepszego trenera kung fu. Zaowocowało to charakterystycznym dla tradycji i związanej z tym kultury chińskich ASW przyjęciem do wewnętrznego grona uczniów rodu Chen, co odpowiada swego rodzaju adopcji. Tego zaszczytu w ramach chińskich ASW dostąpiły na razie w Polsce obok wyżej wymienionego jeszcze tylko dwie osoby ze szkół Ving Tsun kuen i Qixing Tang Lang quan.

\section{Kenjutsu - japoński fechtunek mieczem samurajskim}

W drugiej połowie lat 90. XX w. formują się dwie pierwsze szkoły koryu kenjutsu (historycznej szermierki japońskiej) wraz z całym charakterystycznym ceremoniałem i sposobem kształcenia psychofizycznego, opartym na właściwych im elementach kultury japońskiej: z bezpośredniego przekazu Sekiguchi Taakakiego shihana styl Muso Jikiden Eishin Ryu (z elementami walki naginata - rodzajem japońskiej glewii, w wydaniu pani Shimizu Nobuko) i z bocznej linii przekazu Tenshin Shoden Katori Shinto Ryu.

Ujawniają się również w tym czasie związane z jujutsu i aikijutsu szkoła kenjutsu Takeda Ryu związana z Daito Ryu oraz nieznanego pochodzenia szkoła (najpewniej związana z Takenouchi Ryu jujutsu) mieszkającego w Polsce Japończyka 
Takeuchi Toshimichiego (1945-2007). W 2002 r. zaczyna działać kolejna szkoła koryu kenjutsu z bezpośredniego przekazu Inaby Minoru shihana Kashima Shin Ryu, a dwa lata później - Narazaki Nobuki shihana Shinkage Ryu. W tym samym czasie do Polski trafia wojskowa odmiana kenjutsu rozwinięta w okresie międzywojennym XX w. - Toyama Ryu.

\section{Kyudo - japońskie tradycyjne lucznictwo}

W drugiej połowie lat 90., poprzez osiadłych w kraju Japończyków, powstają w Łodzi i w Warszawie pierwsze dwie grupy tradycyjnego łucznictwa kyudo, by na początku XXI w. rozwój ten nabrał tempa dzięki wiedzy i pomocy Morimoto Takashiego sensei, dyrektora szkoły japońskiej, który podczas kilkuletniego pobytu w Warszawie postanowił zapoznać chętnych z tą częścią kultury swego kraju.

$$
* \quad * \quad *
$$

Początek XXI w. rodzi nową jakość w ASW. Wielu wytrenowanych w kraju adeptów zaczyna pracować i ćwiczyć, na stałe mieszkając w Chinach i w Japonii w ramach wieloletnich kontraktów zawodowych bądź zakładając tam rodziny. Intensyfikuje się jednocześnie wymiana pomiędzy poszczególnymi szkołami i niejako przy okazji międzykulturowa, bo wizyty w tamtym regionie obejmują również inne niż sztuki walki aspekty kultur azjatyckich. Reprezentacje poszczególnych systemów uczestniczą w międzynarodowych konferencjach naukowo-badawczych i związanej z tym wymianie doświadczeń.

\section{Rola periodyków i ksiq̨żek drugiego obiegu czasów PRL w upowszechnianiu ASW}

Nie sposób pominąć tu roli, jaką w rozwoju polskich szkół ASW odegrała w latach 70. i następnych firma Ars Polona, zajmująca się importem obcojęzycznych publikacji również na indywidualne zamówienia. Setki książek sprowadzonych tą drogą zostało potem przetłumaczonych i upowszechnionych w drugim obiegu (w kraju nie honorowano $\mathrm{w}$ tym czasie zagranicznych praw autorskich, więc nikt tego nie kontrolował ani nie ścigał). Po te publikacje pielgrzymowały do połowy lat 80. na warszawskie bazary tysiące polskich neofitów ASW.

Od połowy lat 70. prym w upowszechnianiu wiedzy o ASW wiódł w prasie oczywiście „Sportowiec”, potem także „Żołnierz Polski” i gazety związane ze Stronnictwem Demokratycznym. W latach 80. dołączyły do nich: „Perspektywy”, „Po- 
lityka”, „Razem”, „Przekrój”, „Rekreacja Fizyczna”, „Kontynenty” i jako ostatni „Sztandar Młodych”. W tym okresie pojawiły się pierwsze gazety i wewnętrzne gazetki redagowane przez samo środowisko, takie jak „Świat Ving Tsun” czy gazeta o sztukach i sportach walki studentów Politechniki Warszawskiej.

Lata 80. to także wpływy na niektóre polskie środowiska filozofii tybetańskiej tantry, której wiele elementów było wspólnych także dla Chin i Japonii (miała wpływ między innymi na początki i kształt chińskiego chan, japońskiego i koreańskiego zen). Te tradycje religijno-filozoficzne znacząco wpłynęły na kulturę azjatyckich wojowników, od których wywodzi się wiele odmian ASW. Szczególną pozycję zaczął zajmować w Polsce koreański zen (sŏn). Wraz z tymi wpływami pojawiły się thumaczenia jego opracowań teologicznych oraz tych związanych ze sposobami praktyk medytacyjnych.

Zainteresowanie kulturą Azji spowodowało, że za pośrednictwem oficjalnych wydawnictw państwowych do obiegu trafiało również coraz więcej książek na ten temat: naukowych, historycznych i podróżniczych.

W latach 90. i na początku XXI w. ukazywało się już wiele czasopism, z których największe oddziaływanie na środowisko miały: „Czarny Pas”, „Wojownik”, „Karateka”, „Budokan”, renomowane magazyny ASW „Samurai” i „Kung Fu” (potem przekształcony w „Karate/Kung Fu”), wreszcie redagowane na najwyższym poziomie „Budojo”. Aktualnie na krajowym rynku istnieje w tym zakresie duża nisza wydawnicza.

\section{Kiedy ASW bywa sztuką i kiedy niq̨ nie jest, czyli Droga nie zawsze prosta}

W latach 80. w Ognisku TKKF Stadion w Warszawie odbywały się Letnie Akademie Kung Fu (pomysłu autora), kontynuowane potem jako cykliczne zajęcia seminaryjne. Uczestniczyły w nich setki osób z kilkudziesięciu miejsc w Polsce, gdzie z czasem powstały samodzielne grupy ćwiczebne. Równocześnie jeden z instruktorów wu shu we współpracy z gazetą „Rekreacja Fizyczna” organizował doroczne Olimpiady Wiedzy o Kulturze Dalekiego Wschodu z finałami w tymże ognisku TKKF. W efekcie ich uczestnicy sięgali do literatury fachowej, zmienił się także sposób przedstawiania sztuk walki w opracowaniach prasowych, jakkolwiek w latach 80 . były one przepełnione naiwną mistyką i własnymi pomysłami autorów dotyczącymi źródeł i tajemnic ASW. Trwał wtedy jeszcze w najlepsze (nie tylko w Polsce) koniec okresu romantycznego ASW. Powodowało to czasami takie żenujące i humorystyczne zbitki jak utożsamienie twórcy chińskiego chan (japońskiego zen) Bodhidharmy (ok. 470-543) z brytyjskim księciem Buckinghamem 
(Georgem Villiersem, 1628-1687, pierwszym księciem Buckingham). W końcu i tu „Be”, i tam „Be”.

Warto tu też wspomnieć o ujawniających się różnych wątkach natury psychologicznej i socjologicznej związanych z ASW oraz inspirowanych Azją ich odpowiednikach rodem z Europy.

1. Ten przypadek, wcale nie odosobniony, miał miejsce w czasie stanu wojennego w 1983 r. Grupa instruktorów i zaawansowanych adeptów jednej z sekcji chińskich ASW Politechniki Warszawskiej „obstawiała” punkt opatrunkowy w kościele św. Anny w czasie warszawskich pochodów rocznicowych związanych z 13 grudnia. Kiedy kolejne zmagania mieszkańców Warszawy z kordonami ZOMO dobiegły końca, jeden z kolegów wyruszył do domu. W wąskich uliczkach Starego Miasta zaczęło go gonić trzech milicjantów w hełmach z plastikowymi przyłbicami, uzbrojonych w długie pałki i tarcze. W pewnym momencie uciekinier, odzyskując kontrolę psychiczną nad stresem wywołanym sytuacją i - jak potem mówił - myśląc, że może być wydalony z uczelni, gdy go złapią, nie mając nic do stracenia, zrobił w tył zwrot i ruszył biegiem w ich kierunku. Po chwili nadciągający z pomocą zobaczyli trzech milicjantów w pełnym rynsztunku uciekających bez oczekiwanej konfrontacji, a za nimi biegnącego kolegę, który skręcił i zniknął w bocznej ulicy.

2. Lata 80. to tysiące ćwiczących nie zawsze mających motywacje związane z doskonaleniem psychofizycznym, w większości szukających jedynie wrażeń, kierujących się modą czy po prostu potrzebą bycia w jakiejś grupie. I tak jednego dnia funkcjonowała grupa ćwiczebna, a drugiego do klubu lub ogniska TKKF docierała informacja, że cała grupa zasiliła na przykład rozwijający się wtedy silnie tzw. ruch oazowy w Kościele katolickim.

Po takich doświadczeniach ze słabymi emocjonalnie jednostkami, niepasującymi do wymogów stawianych przez ASW, już w latach 90. niektórzy zaczęli dostrzegać w tym szansę na wykreowanie siebie i ideologii opartej na poglądzie (niczym niepotwierdzonym), że ASW wywodzące się z kultury azjatyckiej, jeśli same nie są sektami, to stanowią co najmniej przedsionek do tworzenia się różnych sekt (jakkolwiek przez niemal 80 lat rozwoju ASW w Polsce żadna sekta w tym środowisku się nie objawiła). W prasie przetoczyła się szeroka i długotrwała dyskusja, która niczego nie wyjaśniła.

Te działania wywołały jednak inną ciekawą reakcję, szczególnie w środowiskach ćwiczących różne odmiany samoobrony rodem z europejskiego i polskiego podwórka, inspirowane jedynie Azją. W rozprawach teoretycznych mających aspiracje naukowe i stanowiących w założeniu nadbudowę dla różnych kursów samoobrony pojawiło się mnóstwo cytatów z Jana Pawła II, zestawianych przypadkowo z innymi równie ważkimi wypowiedziami pochodzącymi także z innych kultur. Jakby tego było mało, co zaradniejsi załatwili sobie ćwiczących duchownych, eks- 
ponowanych potem w prasie i w Internecie. Ruchy i stowarzyszenia o szerszym, ogólnopolskim zakresie działania, jeżeli nie miały takich ćwiczących duchownych, to znalazły sobie jako „kapelana” księdza, popa lub rabina.

3. W 1984 r. z powodów komercyjnych, ale inspirowanych ideologiczną obawą o „bezpieczeństwo socjalistycznego państwa” w warszawskiej AWF odbyła się konferencja mająca doprowadzić do likwidacji Rady Instruktorów Kung Fu przy ZG TKKF, a w dalszej perspektywie do zakazu ćwiczenia w Polsce chińskich sztuk walki. Jej inspiratorami byli znani działacze środowiska karate ze Szczecina i z Krakowa. Dowodzili, że chińskie ASW to umiejętności realnej walki, a ze względu na szeroki i powszechny wtedy ruch sprzeciwu społecznego mogą one być poważnym niebezpieczeństwem dla służb porządkowych. Swoje stanowisko wzmacniali legitymacjami partyjnymi. W związku z tym ostatnim argumentem organizatorzy konferencji zwrócili się o salomonową opinię „w sprawie” do obecnego na tym spotkaniu ówczesnego naczelnika Wydziału Zabezpieczenia Komendy Głównej Milicji Obywatelskiej (wydziału koordynującego między innymi ówczesne jednostki antyterrorystyczne). O dziwo ten nie podtrzymał obiekcji organizatorów konferencji i tak polityce nie udało się wtedy wkroczyć do tradycyjnych ASW. Wydawać by się mogło, że te zdarzenia to odległe już czasy. Nic bardziej błędnego.

W latach 2000-2001 w ramach zespołu doradców zajmujących się sportami i sztukami walki przy przewodniczącym ówczesnego Urzędu Kultury Fizycznej i Turystyki toczyła się dyskusja dotycząca powołania związków sportowych znów środowisk chińskiego sportu wu shu i tradycyjnego kung fu. I po raz kolejny kluczowymi argumentami były nie liczba ćwiczących czy sukcesy międzynarodowe, ale legitymacje partyjne. Tym razem ,jedynie słusznie" prawicowe. Sprawę zamknął i uspokoił emocje ówczesny zastępca dyrektora Departamentu Sportu i jednocześnie jeden z nestorów oraz twórców polskiego judo. W efekcie tego typu dyskusji powołano jednak tylko Polski Związek Wushu. 
O ile kendo, karate, judo, taekwondo są dyscyplinami sportu, w niektórych przypadkach nawet olimpijskimi, bo taka była idea ich tworzenia, aikido, jujutsu i kenjutsu zaś dyscyplinami sportu nie są, o tyle klasyfikacja niektórych odmian ASW rodzi pewne problemy na Zachodzie i w Polsce.

Przykładem jest pochodzące z Okinawy karatedo. Na początku XXI w. działacze federacji międzynarodowych zrzeszających kluby japońskich odmian karate zaangażowanych w rywalizację sportową podjęli starania, by Japonia poparła ich aspiracje do włączenia tej dyscypliny w rywalizację olimpijską. Po konsultacjach ze związkami i mistrzami w miejscu narodzin karate, zwanego kiedyś tode, czyli chińską ręką, a współcześnie karatedo, na Okinawie, odpowiedź na razie jest odmowna.

Kolejnym przykładem są chińskie sztuki/sporty walki. Taki rodzaj aktywności jak kung fu mające ponad dwa tysiące lat tradycji, by mozna go pojąć z pozycji człowieka Zachodu, wymaga nie tylko predyspozycji fizycznych i mentalnych, ale i zainteresowania właściwymi poszczególnym systemom czy stylom kulturą chińską i filozofiami. I w odróżnieniu od większości sportów walki, nawet ze słowem „tradycyjne” w nazwie, kariery nie kończy się w nim po dziesięciu latach.

Marsz w kierunku sportu i formy kultury fizycznej dla szkół kung fu zaczął się w 1909 r., kiedy w Szanghaju powołano Towarzystwo Sportowe Jingwu (Chin Wu). Obecnie poza kilkudziesięcioma oddziałami w samych Chinach ma ono agendy w wielu krajach świata. W tym okresie nie używano jeszcze jednej wspólnej nazwy dla ogółu chińskich sztuk walki. Po powstaniu Republiki Chińskiej (1912) w 1928 r. powołano Centralny Instytut Guo Shu w Nankinie, który przyjął dla chińskich sztuk walki wspólną nazwę guo shu (kuo $s h u$ - sztuka narodowa). W instytucie stworzono nowe, uproszczone style, które miały być podstawą chińskiej kultury fizycznej i przeznaczone do nauczania w szkołach. Doświadczenia te przerwała II wojna światowa.

Po 1949 r. i utworzeniu ChRL na bazie doświadczeń instytutu z Nankinu stworzono nową teorię, która została zaniechana na wiele lat z powodów wydarzeń związanych z ,rewolucją kulturalną". W latach $80 . \mathrm{XX}$ w. powstały na tej bazie sportowe wersje chińskich sztuk walki pod wspólną nazwą wu shu (sztuka wojenna - walki). Sportowe wu shu zaczęło marsz na światowe salony w 1985 r., by na igrzyskach w Pekinie znaleźć się wśród dyscyplin pokazowych.

Typowe podejście ludzi Zachodu do analizy różnych zjawisk społecznych polega na redukcji i unifikacji chociażby działań ruchowych, co ma się nijak do azjatyckich kultur, konotacji ze stresem i kształceniem psychiki właściwej dla adeptów ASW. Metody i cele treningu dla różnych odmian ASW były i pozostają różne. W przypadku sztuk walki jest to forma długofalowego kształcenia i wychowania, a nie poszukiwanie krótkiej drogi zakończonej chwilowym sukcesem, jak to się dzieje w sportach walki.

Kluczem ćwiczenia ASW dla dużej części polskich adeptów - co potwierdzają badania prowadzone przez autora - było i jest przede wszystkim zdrowie, w tym 
sprawność fizyczna, a przy okazji nabycie psychofizycznych umiejętności walki lub samoobrony oraz oceny $\mathrm{z}$ tej perspektywy innych zjawisk ujawniających się w życiu codziennym.

Fizyczna strona trenowania ASW w Azji sprowadzała się i sprowadza nadal do walki jedynie w obronie zdrowia i życia, bo tylko taka ma sens, i trwa zwykle do kilkunastu sekund. Gdyby w tym treningu chodziło jedynie o aspekt fizyczny, to powstaje kluczowe pytanie, czy dla tych kilkunastu sekund warto poświęcać całe życie. Ćwiczenie ASW wywodzących się z azjatyckich sztuk wojennych ma zatem w Azji nadal zupełnie inny wymiar niż sport w rozumieniu Zachodu. Jakkolwiek kształtuje się tu też postawę zwycięzcy, to przeciwnikiem staje się przede wszystkim własne ego. Sztuki walki uczyły kiedyś, jak być lepszym wojownikiem, dziś - jak być lepszym człowiekiem. To zaś wymaga znacznie większego wysiłku, bo ogólny poziom bezpieczeństwa życia jest wyższy, co pozwala na pobłażanie sobie, lenistwo czy brak odpowiednich motywacji.

Ponieważ czasy się zmieniły, takie umiejętności dla ludzi Zachodu okazują się przydatne przede wszystkim w życiu codziennym - obok wspominanego dobrego zdrowia - w którym strategie ASW można stosować w biznesie, kontaktach czy w negocjacjach.

System w ASW czy - jakby powiedzieli Azjaci - metoda treningowa strategii walki danej szkoły, są nie tylko zbiorem myśli i związanych z tym ruchów, ale przede wszystkim sposobem myślenia. Ta subtelność odróżnia je od zachodniego podejścia do metod treningowych. Na tym sposobie myślenia oparte są tylko pewne sekwencje ruchów, stanowiące podstawę systemowej metody treningowej. Jak wyjaśnialiby tę ideę średniowieczni japońscy mistrzowie sztuk walki - zen bez fizycznej realizacji staje się jałową dyskusją, a technika walki (strategia) bez realizacji, którą jest umysł, staje się zachowaniem niegodnym.

Z zachodniej perspektywy fizycznej strony konfrontacji, jeśli chodzi o samoobronę, jej praktyk odpowiada jedynie swoim ruchem na ruch przeciwnika. Ten dualizm obecny w metodach treningowych, na przykład kiedy my reagujemy na coś, nie występuje w filozofii systemów ASW, ponieważ tam yin i yang stanowią równoważne aspekty tej samej całości, zdarzenia, ruchu. Tam my i przeciwnik (uzbrojony w broń białą lub nie) razem doświadczamy czegoś jednocześnie, zjednoczeni systemowymi ruchami walki i reakcją umysłu. Praktyk systemu ASW reaguje więc wraz z sytuacją tu i teraz, kierując się nie tylko ruchem, ale wycinkiem przestrzeni, w której postępuje zmiana w postaci zagrożenia, i wyrównując potencjały energetyczne z przeciwnikiem.

Tysiące godzin wysiłku, które praktycy poświęcają na treningi ASW czy, jak mówią na przykład Japończycy, na koryu bujutsu, dają im duże doświadczenie i wiedzę, które zmieniają ich zwykły sposób myślenia i rozumowania. Osiągają oni 
dzięki temu umiejętność przetwarzania większych zestawów systemowej wiedzy strategicznej, tworząc pamięć długoterminową (ślady pamięciowe wtórne, trwałe, o teoretycznie nieograniczonej pojemności i czasie przechowywania).

Do prawdziwie tradycyjnych ASW dostęp nadal mają jedynie ci, którzy na to zasłużyli dobrym sercem, wolą, latami poszukiwań i odpowiednim poziomem umysłowym. Kiedyś taki początkujący adept musiał udowadniać swoją gotowość, jak chcą legendy, siedząc na przykład przed progiem domu mistrza w pogodę i niepogodę, dzień, dwa, tydzień... Milarepa, słynny tybetański mistyk z XII w., poddawany był próbom nawet kilka lat.

ASW mimo takich trudnych tradycji stały się jednak we współczesnej Polsce skutecznym i docenianym narzędziem wychowawczym, bo wielu rodziców wysyłających na tego typu zajęcia swoje wyjątkowo aktywne dzieci szybko spostrzega u nich pozytywne zmiany.

Z historycznej perspektywy rozwoju form ASW w Polsce, a szczególnie związanej z tym wymiany kulturowej, wykraczającej poza najlepszą nawet formę ruchową, warto wymienić z pokaźnej grupy znaczących praktyków takie kluczowe nazwiska dla ruchu karate (karatedo), jak: Aleksander Trofimow (1950-2002), pukkownik Leszek Drewniak (1951-2007), Włodzimierz Kwieciński, Andrzej Pyrzewicz, Aleksander Staniszew i Jan Dyduch. Dla ruchu kung fu: Grzegorz Ciembroniewicz, doktor Sławomir Milczarek, Tadeusz Gacki, Jacek Świątkowski, Jaromir Śniegowski, Radosław Mikołajczuk i Mariusz Pietkun. Dla ruchu aikido: Marian Osiński, Jacek Wysocki, Jerzy Pomianowski i Roman Hoffman. Dla ruchu jujutsu i metod mieszanych: Michał Śliwka, Eryk Murlowski i Grzegorz Krauze. Dla ruchu kenjutsu: Janusz Lukaszczyk i Jerzy Pomianowski.

To dzięki nim Polacy są obecnie jednymi z najlepszych na świecie znawców i praktyków ASW, rozumianych tu jako tradycyjne metody walki i szkolenia bojowego. 